\title{
圧力室型エアクッションに関するニ三の実験*
}

\author{
宮井善 弘**.安富善三郎**.木田輝彦**
}

\section{Some Experiments on Open Plenum Chamber Air Cushion}

Yoshihiro Mryal, Zensaburo Yasutomi and Teruhiko KIDA

\begin{abstract}
Some experimental investigations were carried out for axially symmetric open plenum chamber air cushion models.

As to the influence of geometric configurations of a plenum chamber (i. e., chamber height, nozzle diameter and hovering height), the hovering lift performance can be conveniently expressed by using Figure of Merit.

The experiments were also carried out for the effect of the peripheral edge shapes of plenum chamber on the lift performance.

The effect of forward speed on the cushion lift was also tested in a wind tunnel with a moving belt rig.
\end{abstract}

\section{1. まえがき}

本研究に抋いては，軸対称の区它型 $\mathrm{ACV}$ 模型を 用いて実験を行ない，最初に浮上高，压力室高，ノズ ル径などの変化による浮上用空気パワーと揚力との関 係をしらべた.

つぎに, 王力室下端におけるェッジ部の断面形状と 揚力性能との関係について実験を行なった.

さらに, 前進速度によるクッション圧力や揚力性能 なよ゙への影響をしらへるため，走行ベルトを用いて風 洞実験を行なった.

\section{2. 压力室型 $\mathbf{A C V}^{1,2)}$ の性能表示方法}

圧力室内面および地面上の圧力分布は $\mathrm{ACV}$ に㗢く 力を知る上には重要である。これを $p / p$ 无a で示す. ことに $p$ は测定点の静圧， $p_{\imath \max }$ はノズル部におけ

* 昭和 44 年 8 月 8 日原稿受理

** 大阪府立大学工学部

*1 浮揚中の $\mathrm{ACV}$ (揚力 $L$, 浮上高 $h$, 浮揚パワ $P$ の状 態）は一般に用いられている掦力增大率 $A(=L / T)$ ，ま たは本文のような一定パワにおける $A_{h=\infty}\left(=L / T_{k=\infty}\right)$ を 用いて性能をあらわすととができる.

パワー定のときは浮上高hが大きくなるにつれて流昷 $v_{n}$ む) 大となり/ズル全圧 $p_{t}$ が減少する. そとで, $P=p_{i} S_{n} v_{n}=\rho S_{n} v_{h=\infty}{ }^{3} / 2$ (ただし $v_{n} \neq v_{h=\infty}$ のとき $p_{t} \neq$ $\left.\rho v_{h=\infty}^{2} / 2\right)$ と $p_{d}=\rho v_{n}^{2} / 2$ (ノズル動圧) との二式より

$$
\frac{A}{A_{k=\infty}}=\frac{T_{h=\infty}}{T}=\frac{\rho S_{n} v_{k=\infty}^{2}}{\rho S_{n} v_{n}^{2}}=\frac{\left(8 p_{d}\right)^{1 / 3} p_{t}^{2 / 3}}{2 p_{d}}=\left(\frac{p_{t}}{p_{d}}\right)^{2 / 3}
$$
となる。
る空気の全正の最大值（ノズル中央部の全圧）である. なお，との報告ではすべて大気死を零としている.

$\mathrm{ACV}$ の底面積に対する平均のクッション圧力係数 を

$$
\eta_{p}=\left\{(L-T) / S_{b}\right\} / p_{t}
$$

であらわす. ここに $L-T$ はクッション揚力 ( $L は$ 全 揚力, $T$ はノズルより下向きに流出する空気の運動量

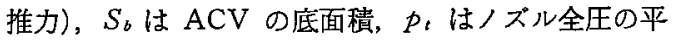
均值である。

つぎに，ある浮上高 $h$ における $\mathrm{ACV}$ の浮上用空 気パワー $P$ は，ノズル部における空文の平均流速を $v_{n}$, 断面積を $S_{n}$ とすると $P=p_{t} S_{n} v_{n}$ で与えられる. いまこの $P$ を一定に保ちながら，第 1 図のように地 面が無限遠方にはなれ，同時に流れが圧力室内壁より 刎離してノズルと同一断面積の噴流になるあのと仮定 すると，ノズル部の静圧は零（大気圧）となるからそ の流速は $v_{n} \rightarrow v_{n=\infty}$ となる. ゆえに, $P=(\rho / 2) S_{n} v_{n=\infty}{ }^{3}$ である.またこの上きの揚力は噴流の運動量推力 $T_{k=\infty}$ $=\rho S_{n} v_{h=\infty}^{2}$ だけであるから $v_{h=\infty}$ を消去するとつぎの ようになる。

$$
T_{n=\infty}=\left(4 \rho S_{n}\right)^{1 / 3} P^{2 / 3}
$$

$\mathrm{ACV}$ の揚力 $L$ と上の $T_{h=\infty}$ との比を浮揚 “パワー $P$ を一定に保ちながら $h \rightarrow \infty$ にしたときの推力を基 準とした揚力増大率” $A_{h=\infty}$ (at const power，以下表 示を略す) と定義する*1.

$$
A_{h=\infty}=\frac{L}{T_{h=\infty}}=\frac{L}{\left(4 \rho S_{n}\right)^{1 / 3} P^{2 / 3}}
$$

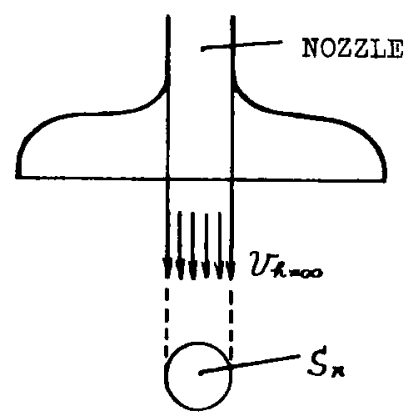

第 1 図 浮上高 $h=\infty$ のときの流れ（仮定） 
ACV のホバリング状態の動力性能は, Figure of Merit $M_{F}\left(=P_{c} / P\right) 〔 \mathrm{ACV}$ の揚力 $L$ と同じ揚力を 基準断面積 $S$ の無損失ダクテット・ファンにより発 生させるときに要するパワー $P_{c}\left(=\sqrt{L^{3} /(4 \rho S)}\right.$ 特性 パワー) を実際の ACV の浮揚パワーPで㫼った值 を用いて表示する. いま基準面積 $S$ として， ACV の底面積 $S_{b}$ あるいはノズル断面積 $S_{n}$ をとったとき の $M_{F}$ をそれぞれ $M_{F b}, M_{F_{n}}$ とすると

$$
\begin{aligned}
& M_{F b}=\sqrt{L^{3} /\left(4 \rho S_{b}\right)} / P \\
& M_{F n}=\sqrt{L^{3} /\left(4 \rho S_{n}\right)} / P=\sqrt{S_{b} / S_{n}} M_{F b}
\end{aligned}
$$

となる. この式より逆江無次元量 $M_{F b}$ を含む式とし て揚力を表示できる，

$$
L=\left(2 M_{F b}\right)^{2 / 3}\left(\rho S_{b}\right)^{1 / 3} P^{2 / 3} \text { * *2 }
$$

式 (3)の $P$ は (5) の $P$ 上等しいから

$$
A_{h=\infty}=M_{F n}{ }^{2 / 3}=\left(S_{b} / S_{n}\right)^{1 / 3} M_{F b}{ }^{2 / 3}
$$

の関係がある.そこで揚力は $A_{h=\infty}$ を含んだ式

$$
L=\left(4 S_{n} / S_{b}\right)^{1 / 3} A_{h=\infty}\left(\rho S_{b}\right)^{1 / 3} P^{2 / 3} * 2
$$

で表わすととができる。

圧力室の幾何学形状および種々の浮上高に対する $M_{F b}$ または $A_{h=\infty}$ の值を模型実験により式（6）ま たは（8）を用いて求めておけば，実際の ACV の揚 力を，その底面積および流体密度とパワーの関数とし て容易に求めることができる. そのため設計が便利と なり，また ACV (周辺噴流型を含めて) を同じ定義 下で取り扱えるため揚力性能の比較が容易である.

\section{3. 実験装置および方法}

ホバリング状態における，ACV に作用する空気力 の測定は第 2 図に示す装固を用いて行なった。供試圧 力室型エア・クッションの模型は第 3 図に示されるよ うに軸対称で，形状の単純化のため圧力室および/ズ ル部はすべて円筒形を採用した。なお圧力室内径Dは $200 \mathrm{~mm} \phi$, 圧力室高さ $h_{b}$ は $0 \sim 100 \mathrm{~mm}$ の籁囲で可 変となっている. また, ノズル内径 $d$ は $39.7 \mathrm{~mm} \phi$, $81,0 \mathrm{~mm} \phi$ および $200 \mathrm{~mm} \phi$ (ノズルだけ) の三種を 用いた。

つぎに，圧力室下端のエッジ部断面形状の影響をし

*2 流体は非粘性，非王縮性であるとし，压力室内に流れの 捐失，うずはないるのとする. また，压力室高 $h_{b}$ は十 分高い之考えノズル眇面内の静圧 $p$ は一定とし，ノズ ル静圧とクッション圧力 $p_{c}$ とは等しいるのとする.と の仮定のもとで揚力を計算すると（文献 5)，

$L=p_{c} S_{b}+\rho v_{n}^{2} S_{n}$

$=\left[\left(\frac{4 S_{n}}{S_{b}}\right)^{1 / 3}\left(\frac{S_{n}}{C_{e} S_{e}}\right)^{2 / 3}\left\{\left(\frac{C_{e} S_{e}}{S_{n}}\right)^{2}+\frac{S_{b}}{2 S_{n}} \eta_{p}\right\}\right]\left(\rho S_{b}\right)^{1 / 3} P^{2 / 3}$

のように表わすととができる．ここにC $C_{8}$ はエッジ部の

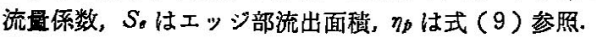
上式の [ ] は ACV の幾何学形状の影響を表わす無次 元量であり， $\left(4 S_{n} / S_{b}\right)^{1 / 3} A_{h=\infty}$ または $\left(2 M_{F b}\right)^{2 / 3}$ とも一致 する.
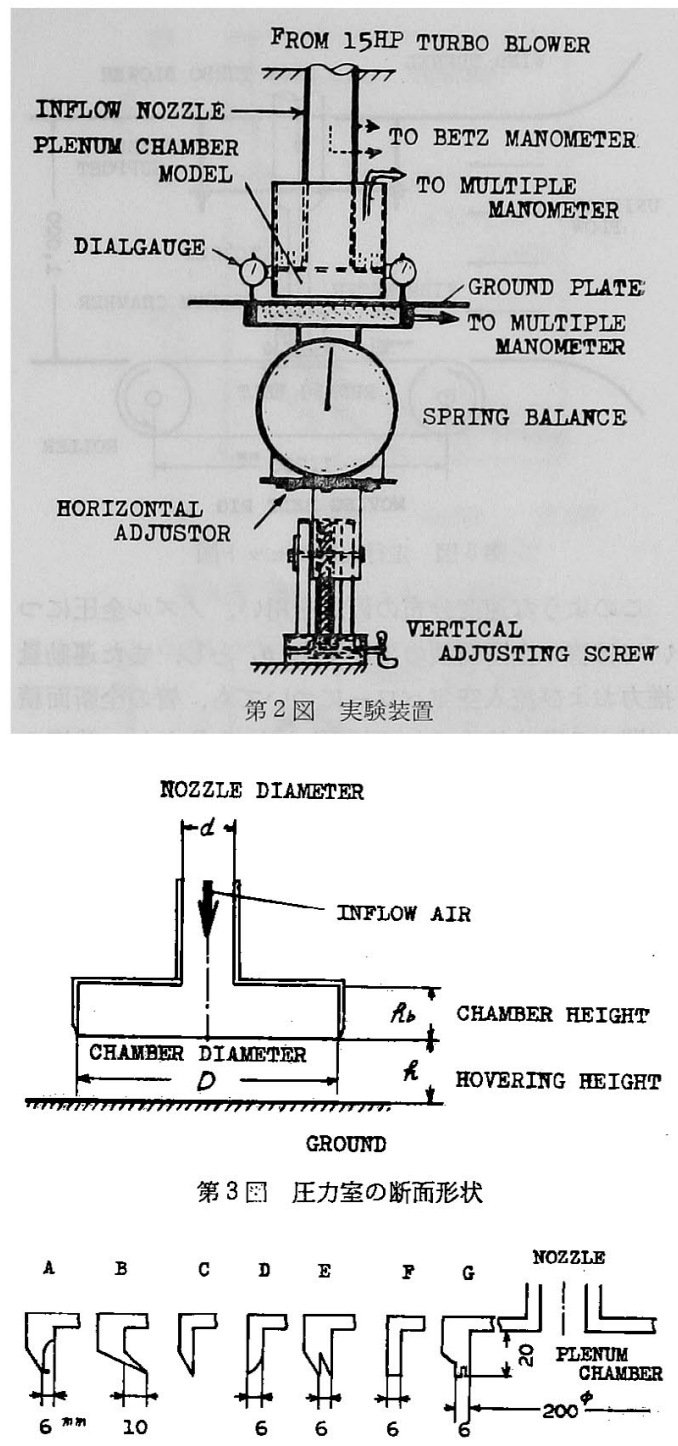

第 4 図 エッジ形状 (断面図)

らべるため，第 4 図に示す 7 種のエッジを用いた. 乙 のうち，A〜D は流出角度を変化させており，他は工 ッジ部に肉厚を持たせたりラビリンスの形状などを取 り入れて空気の流出阻害作用を期待している.

$\mathrm{ACV}$ に作用する全揚力 $L$ は第 2 図の地面板の下 におかれたバ六科で直接求めた。なお $\mathrm{ACV}$ の浮上高 は圧力室の外周に $120^{\circ}$ 間隔で取り付けた三個のダイ ヤル・ゲージで測定した。

ノズル部における流れについては，管の中心軸に設 けられたピトー全王管と管壁の静正孔とにより求め た.すなわち静压の半径方向の変化は刋視し，流れの 軸方向速度は乱流と見なして管壁よりの距離の $1 / n$ に 比例するものと仮定し， $n$ を管内の平均 $R_{e}$ 数より NIKURADSE ${ }^{3)}$ の奏験を用いて定めた. 


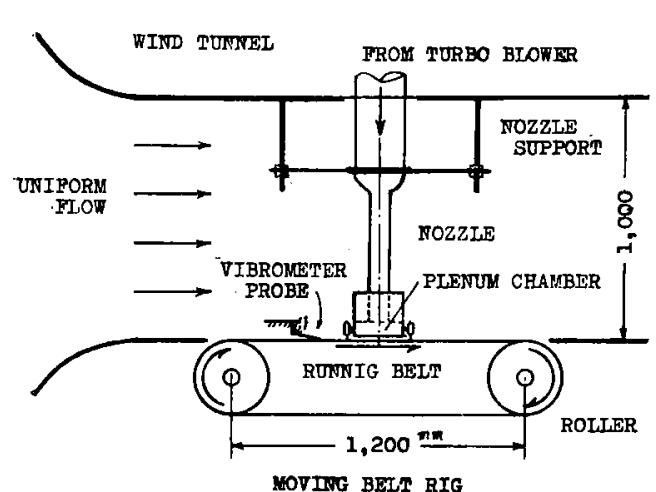

第 5 図走行実験のセット図

このような速度分布の仮定を用い，ノズル全王につ いては管の全断面積の平均値を $p$ 、とし，また運動量 推力および流入空気パワーについても, 管の全断面積 に関する積分值をそれぞれ $T$ および $P$ とし，前節の 式 (1)，（6）および (8) により $\eta_{p}, M_{F b}, A_{b=\infty}$ な どを求めた。

前進速度によるクッション压力や掦力性能などへの 影響をしらべるための実験装置を第 5 図に示す. 風洞 は NPL 型低速風洞で，测定室の断面は $1 \times 1.5 \mathrm{~m}$ の 変形八角形である.との下面中央部に幅 $650 \mathrm{~mm}$ の ベルトを長さ $1,200 \mathrm{~mm}$ にわたって設置し，風洞の 気流速度之同期させだ). ベルトの材質はナイロン芯 入りネオプレン製で，外側の表面は平滑に作られてい る.なお，ローラー直径は中央部で $296 \mathrm{~mm} \phi て ゙ あ り ，$ ベルト面の走行速度の範围は $0 \sim 30 \mathrm{~m} / \mathrm{s}$ である.

模型は風洞に固定し，外部よりパイプを通ってノズ ル部に空気を導入した（模型は静止状態の実験に用い たものと同一で $D=200 \mathrm{~mm} \phi$, 圧力室の断面形は第 4 図F).

走行実験は前進速度係数 $k\left[k=(\rho / 2) U^{2} / p_{i \operatorname{mxx}} \quad\right.$ 乙 こにUは風洞気流の速度]の值を $0 \sim 1.0$ の簀囲で 変化させた. なおこの実験においては，圧力室内部の 上面部に作用する静圧分布を積分したすのに，ノズル 部の静圧による力および運動量推力 $T$ によるすのと を加えて，全揚力 $L$ を計算した．

ベルト面の走行による上下振動の測定には抵抗線歪 み計による変位計を用い電磁オッシログラフで記録し た.

\section{4. 実 験 結 果}

4.1 圧力室の形状による影響 第 6 図は第 3 図の ような珐力室型エア・クッション（ただし，エッジの 断面形は第 4 図 C) の圧力分布を示す．上の曲線群は 圧力室上部内面，下の曲線群は地面板上の王力分布て ある. 压力室上部内面の圧力は, 浮上高 $h$ 加非常に小
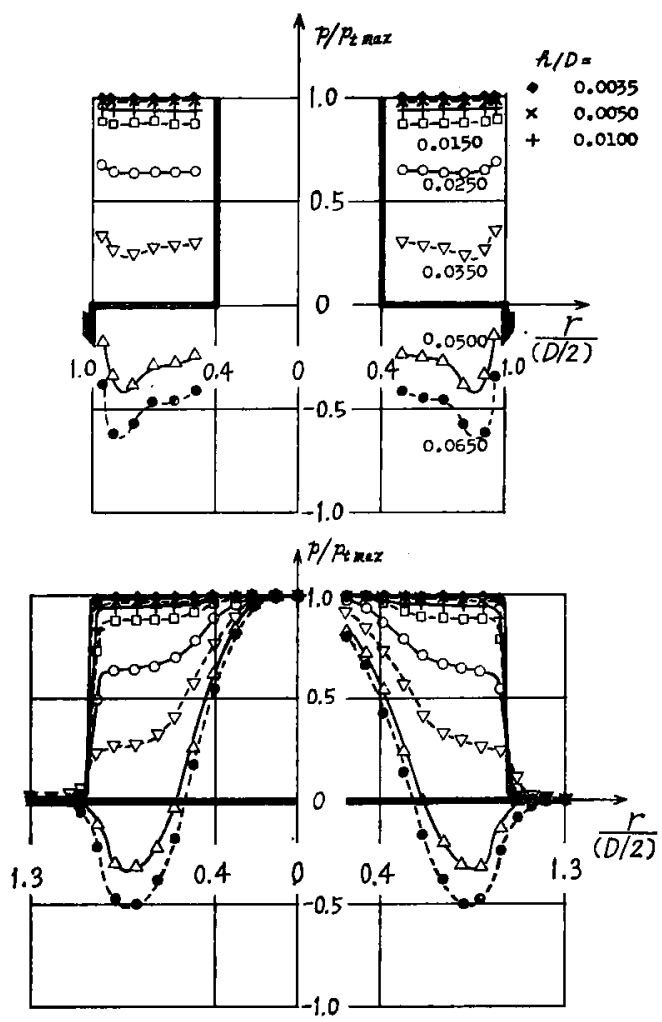

第 6 図静圧分布 $(エ ッ シ ゙$ 第 4 図C)

さいとき $(h / D=0.35 \%)$ は $p / p_{t \max } \fallingdotseq 1.0$ であるが, $h$ が大きくなると王力は降下する， $h / D$ が $3.5 \%$ 以 上になると压力室内径の $85 \%$ 付近において圧力の極 小值があらわれている．てれは圧力室内に佩輪が発生 するためである．また $h / D$ が約 $6 \%$ ぐらいのとき 上部内面の圧力は強い負圧にまで低下している.

第 7 㘠は第 6 図の圧力室 $(d / D=0.405)$ のほ加

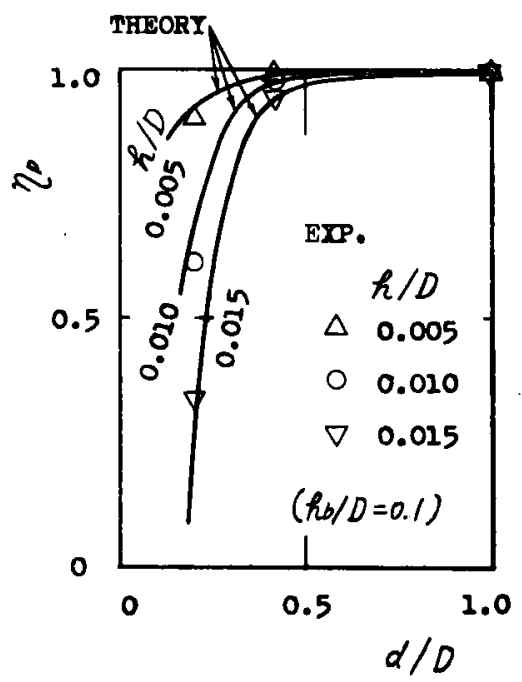

第 7 図 クッション圧力係数とノズル径との関係 


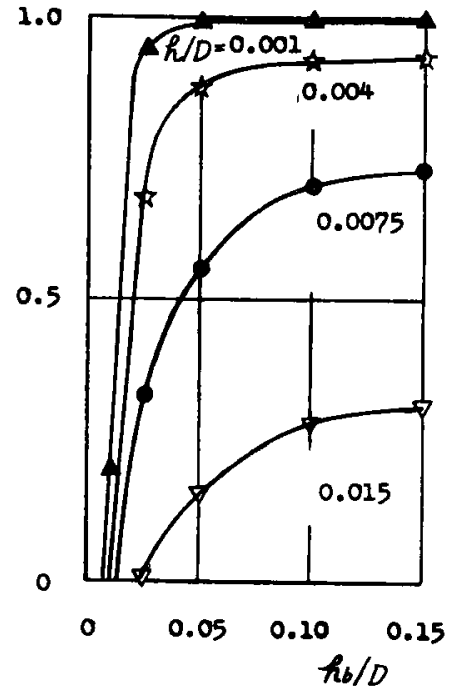

第 8 図 種々の圧力室高に対する浮上高とクッション 圧力係数との関係 $(d / D=0.199)$

$d / D=0.199$ および 1.0 の場合に対して，式（1）を 用いて求めたクッション圧力係数 $\eta_{p}$ と浮上高との関 係を示す. 図中の実線は揚力が正の範囲の理諭値 ${ }^{5}$

$$
\eta_{\mathrm{p}}=1-C_{e}{ }^{2}(2 D / d)^{4}(h / D)^{2},\left(C_{e}=0.6\right)(9)
$$

を示し，O $\nabla \triangle$ はそれぞれ実験值を示す.

第 8 四は圧力室高を変化させた場合の各種浮上高に 対する $\eta_{p}$ の様子を示す. 浮上高が非常に低い場合 $(h / D=0.1 \%)$ の $h_{b} / D \geq 0.05$ のとき，と比較的大き い浮上高 $(h / D=1.5 \%)$ の場合の $h_{b} / D \geq 0.1$ のとき 飞, $\eta_{p}$ の值はおのおの $\eta_{p} \fallingdotseq 0.99$ 之 $\eta_{p} \fallingdotseq 0.31$ 位任収 束している. しかし，おのおのそ朾下の $h_{b} / D$ の場 合には急速に $\eta_{p}$ の值は低下している.

第9図は動力性能 $M_{F b}$ 之浮上高との関係を示して いる. 実線は理諭值 ${ }^{5)}$ で流量係数 $C_{e}$ を 0.6 亿とっ て次式から求められた。

$$
M_{F b}=\frac{1}{4 C_{e}} \frac{D}{h}\left[\frac{\eta_{p}}{2}+\left(\frac{4 C_{e} h}{d}\right)^{2}\right]^{3 / 2}
$$

$h / D$ の全域にわたって $M_{F b}$ の最大值を与えるのは $d / D=1.0$ のときである.浮上高が小さい之きは $d / D$ の値が相当小さくなっても $M_{F b}$ の值はほとんど減少

*3 ノズル径の影響として，文献 1)の計算では $S_{n} / S_{b}=0.5$ のときに $\left(A=L / T\right.$ 脚註 $\left.{ }^{* 1}\right)$ の值加最高值になるとし ている. そして実験では最適ノズル径を見出していな い.

*4文献 1) では，匤力室高は掦力增大率にあまり影堙をお よぼさないとしているか，てれはんっの大きな領域の実 験が主となっているために $h_{b}$ の小さなとてろの評価か 入っていないるのと思われる.また小さな浮上高 $(A \geqq 1)$ のときには压力室高 (side depth) が小さいほど $A$ は 大きくなるとしているか，図から判断し奞く，図中で $h_{b}=0$ のところで $A$ 加大幅に下加っているとと，およ び王力室高の小さいところでの実験值が少ないことな どから信頼性にそしい表現と思われる。

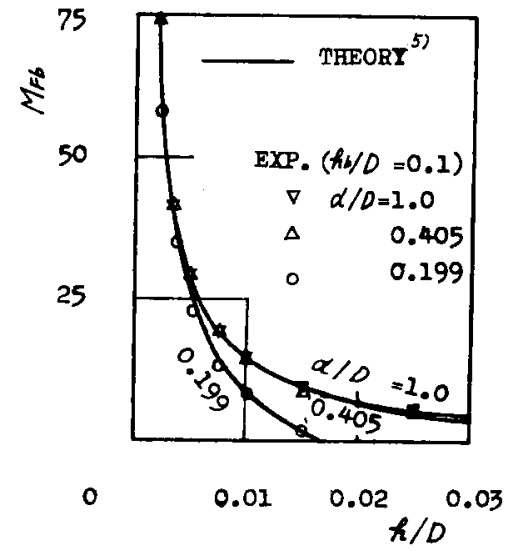

第 9 図 $M_{F b}$ と浮上高との関係

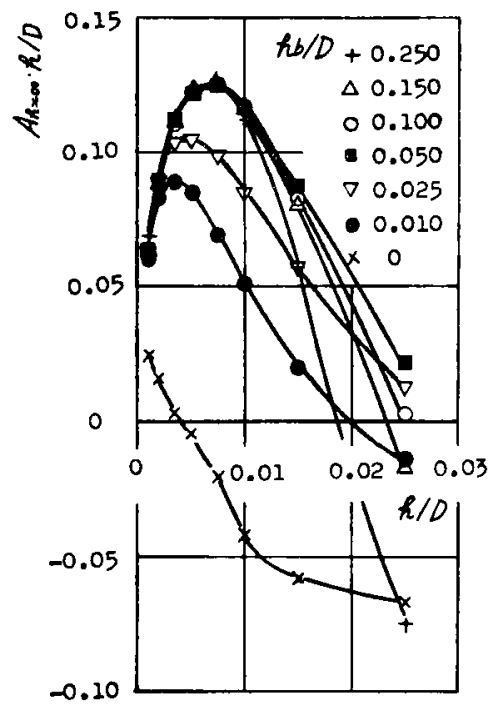

第 10 図 $A_{h=\infty} \cdot h / D$ におよばす王力室高の影響 $(d / D=0.199)$

しないが，浮上高が大きくなると/ズル直径の減少に つれて $M_{F b}$ の值は顕著似減少する傾向がある*3.

第 10 园は文献 6) にならって $A_{h=\infty} \cdot h / D$ の形で揚 力性能をあらわし, 圧力室高 $h_{6}$ の効果をしらべてい る. つまり $A_{h=\infty}$ の大きい值を得る浮上高 $h / D \leq$ 0.01 亿おいて， $h_{b} / D$ が 0.05 以上であると $h_{b}$ の影 響はほ上んどみられないか， $h_{b} / D \leq 0.05$ 飞おいて $h_{b}$ が小さくなるにしたがって $A_{h=\infty} \cdot h / D$ 低下する*4. そして，一般に知られているように $h_{b}=0$ で最す低い 值になっている.なお $d / D=0.058$ と 0.405 の場合 あ同様な結果が得られた。

4.2 エッ汧形状と揚力性能との関係 圧力室下端 に第 4 図に示す各種エッジを取り付けた場合，圧力室 加ら出る空気の流出流量が減少し, 揚力性能が向上す ることを目的として実験を行なった．第11図江压力室 上面部之地面板上の圧力分布の代表例を示す（第 4 図 

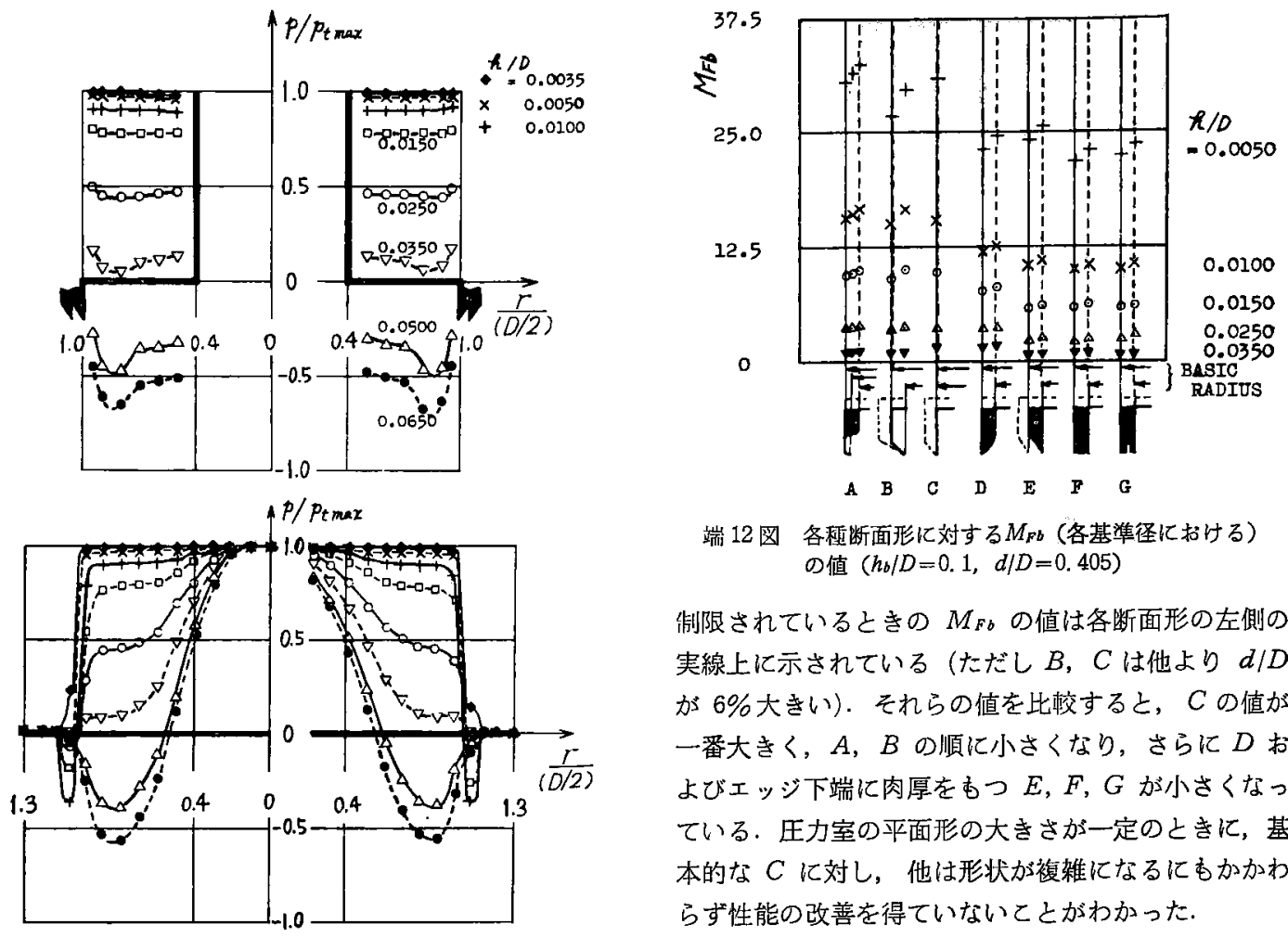

端 12 図 各惁断面形に対する $M_{F b}$ （各基準径におりる） の值 $\left(h_{b} / D=0.1, d / D=0.405\right)$

制限されているときの $M_{F b}$ の值は各断面形の左側の 実線上に示されている(ただし $B, C$ は他より $d / D$ が $6 \%$ 大きい). それらの值を比校すると，Cの值が 一番大きく，A，B の順に小さくなり，さらに $D$ お よびエッジ下端に肉厚をもつ $E, F, G$ が小さくなっ ている. 壬力室の平面形の大きさが一定のときに，基 本的な $C$ に対し，他は形状が複䧴になるにあかかわ らず性能の改善を得ていないととがわかった。

第 11 図 静正分布 (エッジ第 4 图E)

Eのエッジ).

てれらの実験は，上面部につながる側筒をそのまま にしておいて，エッジ部だけを取りかえてその掦力性 能におよぼす勃果をしらべようとしたものであり，実 験はすべて $d / D=0.405, h_{b} / D=0.10$ の圧力室につ いて，浮上高 $h / D=0.5 \% \sim 3.5 \%$ の籁囲に対して行 なわれた。

第 6 図 (エッジ第 4 図 C) と比校すると，第 11 図の 地面板上の圧力分布には $h / D=1 \%$ 2.5\%に加けて エッジの下部に強い真圧があらわれている，乙の負圧 は圧力室外周部の環状面揹に作用するので，揚力を減 少させる効果が比較的大きい，また同椂の現象が第 4 四 $\mathrm{F}$ および $\mathrm{G}$ のようにエッジ下端に厚みのある断面 形状に対してあらわれている.

第 12 図には各種エッジの揚力性能を比校するため Figure of Merit の值が示されている. なお成の下部 にはエッジの断面形を示している. 一般に $M_{F b}$ の值 は底面皘のとり方により变化するので, エッジに肉厚 を持つすのはその外径あるいは内径，またエッジ角度 をむつあのは最下部直径あるいは圧力室最大内径など を基準として求められた。乙てれらの值はそれぞれ各種 エッジ断面の上方に対応させて示してある.

エッジを含めた圧力室の占有する最大面積が一定に つきに, 内径加 $200 \mathrm{~mm} \phi$ の側何に各種のエッッを 取り付けた場合（d/D蛙ずれす一定で $M_{F b}$ の値 は各断面形の右側の点線上に示さ机ている）の性能を 比較すると， $A$ が $C$ より少し上まわっているほかは いずれも $C$ より性能が覀くなっている，特にエッジ 部に肉厚のある $F, G$ は最も低い值を示している. こ

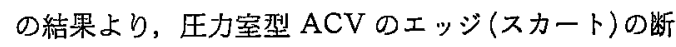
面形状位基本形状 $C$ 以外のものを取り付けても $M_{F}$ はほとんど改善されていない。

4.3 前進速度とクッション揚カとの関係 ノズル 直径 $d / D=0.405$, 压力室高 $h_{b} / D=0.10$ の圧力室模 型を用いて風洞実験を行なった，すなわち，前進速度 係数 $k\left[=(\rho / 2) U^{2} / p_{\mathrm{r} \max }\right]$ の値を 0 より 1.0 まで変 化させ種々の浮上高におけるクッション找力分布を風 洞気流を含む対称面の前, 後半部およびとれに直角な 面内の左右の部分について測定した. てのうち対称面 内に括泟压力室上部内面の压力分布の二, 三の例を 第 13 図に示す $(k=0$ の場合は第 11 図之ほぼ同じ)

$k=0 \rightarrow 0.11$ の筙围では前進速度の増加にともなっ て圧力は全般的任少し減少するが， $k=0.2$ (第 13-2 図）になると特浮上高汃小さい場合 $(h / D<1.5 \%)$ に圧力降下が見られる.とれ以上の速度になると, 圧 力分布の前半部, 後半部の形状がたがいに異なってく る. 特に $k$ の值が 0.5 以上になる之, 浮上高 $h / D$ か 5\% 付近で存在していた前半部の負压は正圧にかわ 


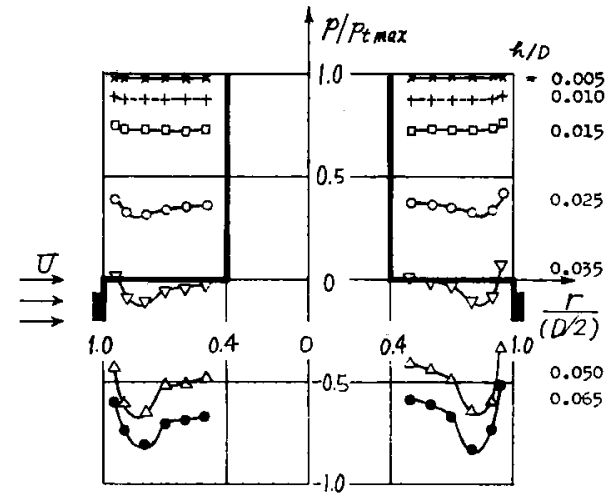

13-1 前進速度係数 $k=0.11$

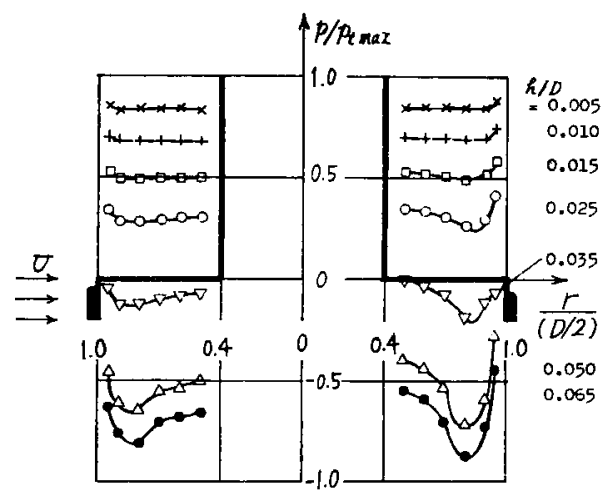

13-2 $k=0.20$

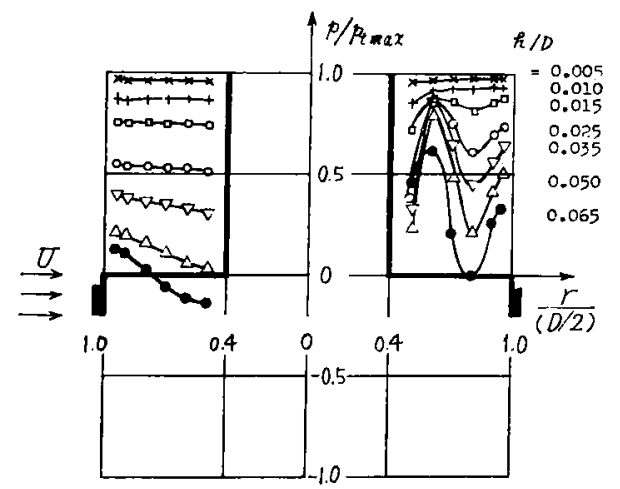

13-3 $k=1.00$

第 13 図走行状態化招ける圧力室上面部の静圧分布

(エッジ第 4 図 $\mathrm{F}, h_{b} / D=0.1, d / D=0.405$ )

りまた後半部の圧力む不規則になって圧力室内径の $60 \%$ 付近で正圧のピークを形成する. この傾向は $k$ $=1.0$ (第 13-3図) になってもほほ同じで，圧力室内 の後半部に複雑な渦が発生しているととを示す.

第 13 図の圧力分布に対応するクッション压力係数 $\eta_{p}$ 第 14 図汇示す．第 13 図に拉ける圧力分布の前 半部之後半部扣上びその分割線上（左右）の圧力分布 はそれぞれ圧力室平面形の四半円の各部の圧力分布を

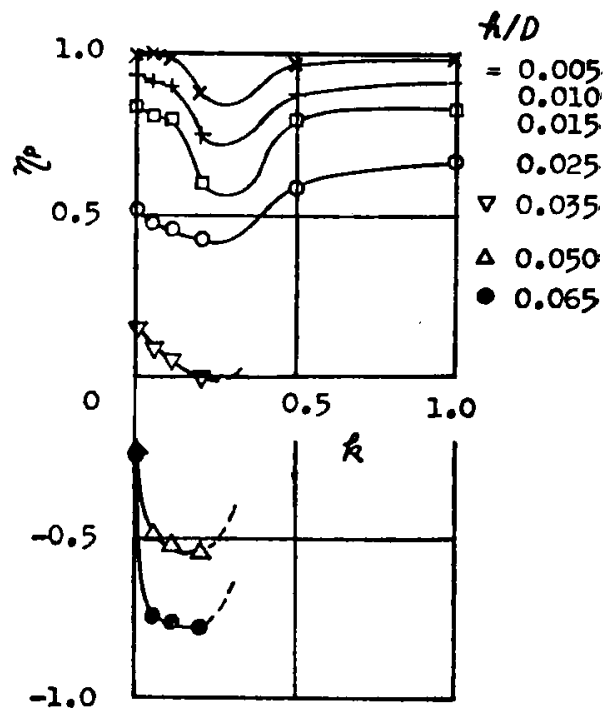

第 14 図 クッション圧力係数と前進速度係数との 関係 $\left(h_{b} / D=0.1, d / D=0.405\right)$

代表するすのと仮定し，乙れら压力分布加ら王力室上 面部に作用するクッション掦力を求め，てれにノズル 部の静圧による揚力を加えて $\eta_{r}$ を求めた（第 14 図 に示された実験点の範囲において，左右の圧力分布は 前後部の圧力分布值のほほ中間值となった)

てのようにして得られたクッション揚力にノズルに おりる運動量推力を加えて全掦力を計算し，前進速度 係数 $k$ に対する “一定動力のもとにおける揚力増大 率” $A_{h=\infty}$ を求めると第 15 図のようになる．乙の前進 速度の影響をしらべる実験では一つの圧力室模型だけ を用いたので，式（7）よりわかるように Figure of Merit の代りに $A_{n=\infty}$ で前進速度係数 $k$ 亿対する揚 力性能を評価することができる.

$\eta_{p}$ および $A_{h=\infty}$ はともに前進速度によりはじめは

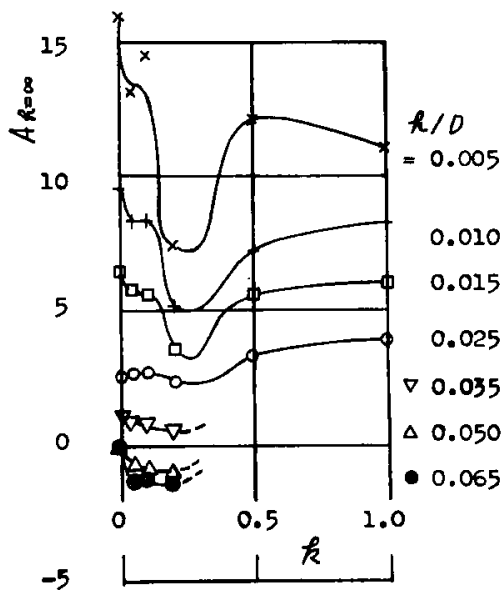

第 15 図 $A_{h=\infty}$ 之前進速度係数との関係 $\left(h_{b} / D=0.1, d / D=0.405\right)$ 


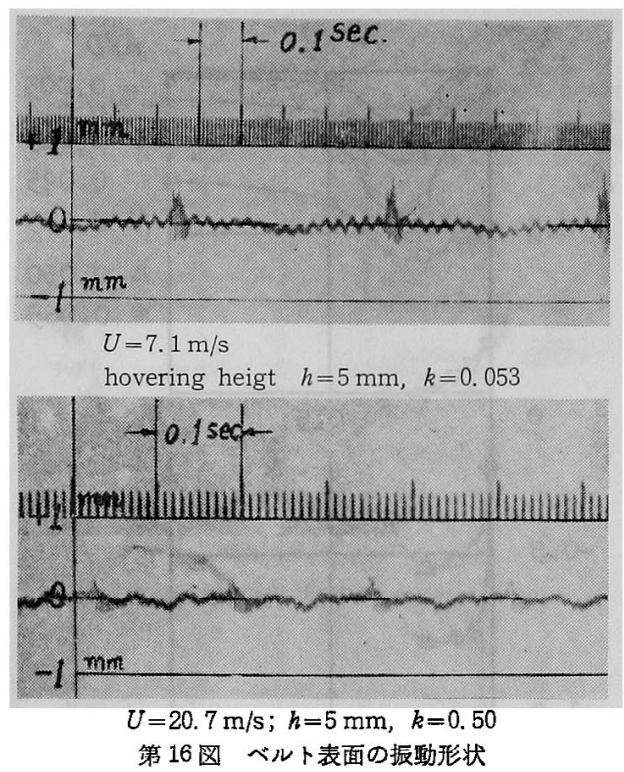

隇少して $k=0.2$ 付近で極小值となり，てれより前進 速度が大きくなると再び增加する傾向がある。

てれらの風洞実験汇おける走行ベルト表面の上下振 動の最大振幅は，走行速度によっても異なるが， $\pm 0.4 \mathrm{~mm}$ 以下であった．乙れは自由振動数の高い変 位計を用いて風洞実験と同時に第 16 図のように電磁 オッシログラフに記録された。

なお,ベルト面の振動が気流および圧力室内の流れ におよに゙す影響は測定していない，しかし，ベルト面 の振幅が非常に小さいため，ほとんど流れの㨨乱を誘 起していないあのと考えられる.

\section{5. 結論}

ノズル部ではく離を起して圧力室に流入するような型 式の圧力室型 $\mathrm{ACV}$ の実験において，つぎの結論を得 た.

（1）最適ノズル直径 $d$ は $d / D=1$ の之きであ る. しかし浮上高 $h$ が小さい場合は性能の低下をおこ さずにノズル径をかなり小さくするととが出来る.

また, 圧力室高 $h_{b}$ は通常 $h_{b} / D \geq 0.1$ の篹囲であ ればよい，そして， $h_{b} / D \leq 0.05$ になると急速に性能
は低下する。

（2）王力室の周辺エッジの断面形を, 基本形（先 端が鋭角で内面が地面上垂直な形) の代わりにラビリ ンス・シール型など数種類のあのを取り付けて実験を 行なったが，掦力性能の改善はほとんど見られず，む しろ悪化する場合の方が多いようである（特にエッジ 部に肉厚のあるあのは性能が悪くなっている).

（3）前進速度がクッション揚力におよ恪す影響 は，最初，前進速度上とすに揚力加低下し，前進速度 係数 $k$ が 0.2 くらいのとき但低值になる. それ以 上 $k$ が大きくなるとクッション揚力は増加しはじめ, $k=0.5 \sim 1.0$ にかけてほとんど静止状態の揚力に近い とてろまで回復している.

(4) ACV の全揚力は， $L=$ (無次元量) $\times(\mathrm{ACV}$ の底面皘 $S_{b} \times$ 空気密度 $\left.\rho\right)^{1 / 3} \times($ 空気 ように表示され，乙の無次元量は ACV の幾何学形状 の影響を表わす.さらに，てれを用いると他種の $\mathrm{ACV}$ とも共通して揚力性能が比較でき，また ACV の設計 も容易になる．乙の無次元量は一般に知られた係数を 用いて表わすと， $\left(4 S_{n} / S_{b}\right)^{1 / 3} A_{h=\infty}$ (at const. power) または $\left(2 M_{F b}\right)^{2 / 3}$ となる。

\section{文献}

1) D. E. WRIGHT: The Effect of Configuration on the Lift Augmentation Ratio of a Two Dimentional Open Plenum Ground Effect Machine, Dep't Aero. Eng. Princeton Univ. Report, No. 516, May, 1960.

2) D. I. G. Jones: Hovering Performance of Plenum Chamber GEMs over Land and Water, J. Aircraft, Vol. 3, July-Aug., 1966, p. 333.

3) J. NikuRAdsE: Forshungsheft, 356, 1932; 藤本武 助, 流体力学, 養蜸堂, 1960, p. 303

4) S. F. J. Butler et al.: A Moving-belt Rig for Ground Simmulation in Low-Speed Wind Tunnels, $R$ \& M, No. 3451, Dec., 1963.

5) 安富他，日本機械学会関西支部第 44 期定時総会㹃演 会請演論文集, 1969 年 3 月, p. 32 .

6) A. JAuMotTE et al.: Theory and Experiments on Air Cushion Vehicles at Zero Speed, Hovering Craft and Hydrofoil, Vol. 4, No. 11, August, 1965. 